\title{
AN EXPLORATORY RESEARCH ON THE PSYCHOLOGY OF INVESTORS IN FINANCIAL MARKETS
}

Mustafa Hakan SALDI ${ }^{1}$

ABSTRACT

Keywords:

Behavioural Finance,

Emotions,

Psychology of Investing,

Neurology,

Endocrine System

JEL Codes:

G40,

G41

\author{
Received Date (Başvuru Tarihi): \\ $1 / 06 / 2020$ \\ Accepted Date (Kabul Tarihi): \\ $3 / 11 / 2020$ \\ Published Date (Yayın Tarihi): \\ $10 / 12 / 2020$
}

The emotional mind which was granted to human beings in order to add the meaning of their perception through the data, information and knowledge that are being gathered from all around the outside environment with senses and the experiences of realities that have effects on the attitude of a person which can be observed as stereotypes, have effects on the decision making processes of investors, which was proven with general assumptions and theories with countless times in the background of the subject. Differently, this research is mainly designed for in-depth investigation of the relationship between parts of the human brain and endocrine system which have a role on emotional actions that can be observed of investors' behaviours in financial markets. From the viewpoint of experimentally tested studies, the discovery of the response of the subproblems will be explored in the main research question of why the risky assets are being selected by the investors relative to the sciences of neurology and endocrinology. Also, the amygdala, testosterone and cortisol relation which is the predictive factor of behaviours is going to be explained in terms of showing their effects on decision making in monetary management and will be analysed as a moderator with depth observations to understand the relationship between investment behaviour and emotions as well. As a result, the study will bring different perspectives to investors who are both experienced and inexperienced in trading with financial instruments by the addition of consideration of emotional side of the human mind to the logic and rational part.

\section{FINANSAL PIYASALARDA YATIRIMCILARIN PSİKOLOJİSI ÜZERİNE KEŞIFSEL BİR ARAŞTIRMA}

$\ddot{O Z Z}$

\section{Anahtar Kelimeler:}

Davranışsal Finansman

Duygular,

Yatırmma Psikolojisi,

Nöroloji,

Endokrin Sistemi

\section{JEL Kodlari:}

G41，

G42
Temel olarak, insanlara bahşedilen duygusal zeka dış çevreden elde edilen verilerin ve bilgilerin algıya dönüşmesinde rol alırken, yaşam tecrübelerinin ve hislerin etkileriyle önyargıların ve basmakalıp düşüncelerin oluşmasına ve yatırımciların karar alma süreçlerine tesir etmektedir tezi, genel varsayımlarla ve teorilerle sayısız kez ispat edilmeye çalışılmıştır. Farklı olarak, bu çalışma insan beyninde ve endokrin sisteminde yatırmmcların finansal piyasalardaki davranışlar üzerinde etkili olan duygusal hareketlerin oluşmasında fonksiyonu bulunan kısımlar arasındaki ilişkiyi derinlemesine araştırmalarla incelemek üzere tasarlanmıştır. Araştırma, deneysel olarak test edilmiş çalışmaların ışığında, esas araştırma konusuna ilişkin alt problemlerin keşfedilerek, yatırımcıların neden riskli varliklara yöneldiği sorunsalın nöroloji ve endokrinoloji bilimleri açısından incelemeyi hedeflemektedir. Bilhassa, çalışmada, parasal iktisatta davranışların tahmini faktörü olarak rol üstlendiği varsayılan amigdala, testosterone ve kortizol ilişkisi, yatırım tutumları ve duygular arasındaki bağıntıyı kavramak için ara değişken olarak derin gözlemlerle analiz edilecektir. Sonuç olarak, bu çalışma, finansal enstrümanlar üzerinden ticaret işlemi gerşekleştirmekte olan tecrübeli veya tecrübesiz fark etmeksizin tüm yatırmmcllara, insan aklının mantıksal ve rasyonel kısımlarına duygusal tarafin etkilerini değerlendirme firsatı sunacaktır.

\footnotetext{
${ }^{1}$ Doktora Öğrencisi, Anadolu Üniversitesi, hamusaldi@hotmail.com,
}

http://orcid.org/0000-0001-5043-4606

Business \& Management Studies: An International Journal Vol.:8 Issue:4 Year:2020, 979-992

Bu makale, araştırma ve yayın etiğine uygun hazırlanmış ve Tị̛nentictete intihal taramasından geçirilmiştir. 


\section{INTRODUCTION}

Fundamentally, emotions are discussed as a significant part of the psychological activities which frames a person's perceptions and experiences of facts. Correspondingly, the internal expressions and perceptual mappings of realities are being performed through neuropsychological processes which can be considered as the signs of personal characteristics that reflect the behaviours of human beings. Conceptually, the needs of living organisms have a crucial role in the emotions which can be reflected by survival instincts that come up from the born as a nature of all the alive objects. In essence, organisms need to regulate their emotions depend on their requirements and external conditions. Therefore, in assumption, from the simple point of view, the risk-taking behaviours of the human beings in financial markets can vary concerning to their living needs as healthcare, food, beverage, insurance or housing and motives, at first, because of the primitive instincts which were coded to the genes of deoxyribonucleic acid (DNA) and drive all the living things to survive and sustain their life.

Similarly, emotions can be explained as the assessment process of information and knowledge which are received by the brain and transformed into perceptions, experiences or subjective representations. So, the emotions which can be defined as the forms of reflections of the stimulus that causes risk-taking behaviour generates irrationality which results as profits or losses in trading activities were added to conventional finance as behavioural or neural part of human beings. In essence, the classical or standard finance which was developed by considering each of the human beings as a rational thinking machine was improved with the addition of emotional factors to the investment decisions are described as behavioural finance. Therefore, behavioural finance can be explained as a universal set which covers both rational and irrational part of the human beings. Briefly, the premise of this research study is that the psychology of investors can be controlled by training the related parts of the brain and as a result, the trading performance can be enhanced with taking the support of the emotions. So, this study is designed to show the emotions as a supplement part of the investment rather than an obstacle, because decision-making processes require sentiments for reacting in risky markets such as stock and derivative. 


\section{LITERATURE REVIEW}

The former studies explain and dig in the subject through the comparison of behavioural finance and price action theories in the conventional finance by just limiting the complexities with tangential approaches and not interacting with the natural part of the human beings.

Table 1. Previous Researches Related with Subject

\begin{tabular}{|c|c|c|c|}
\hline $\begin{array}{c}\text { Author and } \\
\text { Year }\end{array}$ & Article Name & Subject and Scope & Findings \\
\hline $\begin{array}{l}\text { M. Statman } \\
\text { (1995) }\end{array}$ & $\begin{array}{l}\text { Behavioural } \\
\text { Finance versus } \\
\text { Standard } \\
\text { Finance }\end{array}$ & $\begin{array}{c}\text { Behavioural finance } \\
\text { demonstrates a modified } \\
\text { frame of human attitudes } \\
\text { can be structured with } \\
\text { prospect theory, issues of } \\
\text { self-control and cognitive } \\
\text { misconceptions }\end{array}$ & $\begin{array}{l}\text { People who support their investment } \\
\text { approaches with standard finance } \\
\text { theories are rational, on the other } \\
\text { hand, people who shape their ideas } \\
\text { according to the market behaviour } \\
\text { are standard, and as a result, they can } \\
\text { be affected by chaotic conditions } \\
\text { which show their effects as biases } \\
\text { and controlling difficulties. }\end{array}$ \\
\hline $\begin{array}{l}\text { Eugene F. Fama } \\
\qquad(2000)\end{array}$ & $\begin{array}{l}\text { Market } \\
\text { Efficiency, } \\
\text { Long-Term } \\
\text { Returns, and } \\
\text { Behavioural } \\
\text { Finance } \\
\end{array}$ & $\begin{array}{l}\text { The conflict between } \\
\text { efficient market theory } \\
\text { and long-term return } \\
\text { anomalies }\end{array}$ & $\begin{array}{l}\text { Efficient markets cover the } \\
\text { anomalies, which can be perceived } \\
\text { with the overreaction of the investors } \\
\text { and can be called as outputs of } \\
\text { chance as well. }\end{array}$ \\
\hline $\begin{array}{l}\text { Jay R Ritter } \\
\text { (2003) }\end{array}$ & $\begin{array}{l}\text { Behavioural } \\
\text { Finance }\end{array}$ & $\begin{array}{l}\text { Represents a brief outset } \\
\text { to behavioural finance }\end{array}$ & $\begin{array}{l}\text { The design of behavioural finance } \\
\text { has been activated by the } \\
\text { incompetence of the conventional } \\
\text { perspective for clarifying stock } \\
\text { market patterns of market bubbles in } \\
\text { history }\end{array}$ \\
\hline $\begin{array}{c}\text { Nicholas } \\
\text { Barberis and } \\
\text { Richard Thaler } \\
\text { (2003) }\end{array}$ & $\begin{array}{c}\text { A Survey of } \\
\text { Behavioural } \\
\text { Finance }\end{array}$ & $\begin{array}{l}\text { Two blocks which were } \\
\text { stated as limits to } \\
\text { arbitrage and psychology }\end{array}$ & $\begin{array}{l}\text { Presenting practices of behavioural } \\
\text { finance in the stock market, } \\
\text { individual trading and corporate } \\
\text { finance }\end{array}$ \\
\hline $\begin{array}{l}\text { Robert J. Shiller } \\
\qquad(2003)\end{array}$ & $\begin{array}{l}\text { From Efficient } \\
\text { Markets } \\
\text { Theory to } \\
\text { Behavioural } \\
\text { Finance } \\
\end{array}$ & $\begin{array}{l}\text { The development of } \\
\text { theoretical approaches in } \\
\text { finance }\end{array}$ & $\begin{array}{l}\text { The combination of finance and } \\
\text { social sciences, especially psychology } \\
\text { part, has presented new aspects to } \\
\text { the conventional economics theories. }\end{array}$ \\
\hline $\begin{array}{c}\text { Andrew W. Lo } \\
(2005)\end{array}$ & $\begin{array}{l}\text { Reconciling } \\
\text { Efficient } \\
\text { Markets with } \\
\text { Behavioural } \\
\text { Finance: The } \\
\text { Adaptive } \\
\text { Markets } \\
\text { Hypothesis } \\
\end{array}$ & $\begin{array}{l}\text { A new framework was } \\
\text { named as Adaptive } \\
\text { Markets Hypothesis was } \\
\text { recommended to } \\
\text { supplement the Efficient } \\
\text { Markets Hypothesis }\end{array}$ & $\begin{array}{l}\text { The thesis of behaviouralists which } \\
\text { can be defined as violations of } \\
\text { rationality which have conflicts with } \\
\text { efficient market theory, can be } \\
\text { smoothed with adaptive markets } \\
\text { hypothesis. }\end{array}$ \\
\hline $\begin{array}{l}\text { S. P. Kothari, } \\
\text { Jonathan } \\
\text { Lewellen and }\end{array}$ & $\begin{array}{l}\text { Stock Returns, } \\
\text { Aggregate } \\
\text { Earnings } \\
\text { Surprises, and }\end{array}$ & $\begin{array}{l}\text { Investigation of the stock } \\
\text { market's returns with the } \\
\text { correlation of news of } \\
\text { earning reports. }\end{array}$ & $\begin{array}{l}\text { Stock market returns are not heavily } \\
\text { related to the historical record of } \\
\text { earning statistics. }\end{array}$ \\
\hline
\end{tabular}




\begin{tabular}{|c|c|c|c|}
\hline $\begin{array}{c}\text { Jerold B. } \\
\text { Warner (2006) }\end{array}$ & $\begin{array}{l}\text { Behavioural } \\
\text { Finance }\end{array}$ & & \\
\hline $\begin{array}{l}\text { Kenneth A. Kim } \\
\text { and John R. } \\
\text { Nofsinger } \\
\text { (2007) }\end{array}$ & $\begin{array}{l}\text { Behavioural } \\
\text { Finance in Asia }\end{array}$ & $\begin{array}{l}\text { Considering the question } \\
\text { of why behavioural } \\
\text { finance is discussed as a } \\
\text { significant issue in Asia }\end{array}$ & $\begin{array}{l}\text { The behavioural finance is perceived } \\
\text { as a significant subject in comparison } \\
\text { with other parts of disciplines of } \\
\text { economics in Asia. }\end{array}$ \\
\hline $\begin{array}{l}\text { Victor Ricciardi } \\
\text { and Helen K. } \\
\text { Simon (2008) }\end{array}$ & $\begin{array}{l}\text { What is } \\
\text { Behavioural } \\
\text { Finance? }\end{array}$ & $\begin{array}{l}\text { Cognitive elements and } \\
\text { emotional issues rather } \\
\text { than modern portfolio } \\
\text { theory (MPT) and efficient } \\
\text { market hypothesis (EMH) }\end{array}$ & $\begin{array}{l}\text { Providing strategies to enhance the } \\
\text { investors' decision-making processes } \\
\text { through perceiving the mental } \\
\text { mistakes and emotional traps while } \\
\text { they are investing in the economic } \\
\text { environment. }\end{array}$ \\
\hline $\begin{array}{l}\text { İlhan Ege, Emre } \\
\text { Esat Topaloğlu } \\
\text { and Dilek } \\
\text { Coşkun (2012) }\end{array}$ & $\begin{array}{l}\text { Behavioural } \\
\text { Finance and } \\
\text { Anomalies: } \\
\text { Testing of } \\
\text { January } \\
\text { Anomaly at } \\
\text { ISE } \\
\end{array}$ & $\begin{array}{l}\text { The behavioural factors of } \\
\text { stock market returns are } \\
\text { examined to test the } \\
\text { efficient market } \\
\text { hypothesis. }\end{array}$ & $\begin{array}{l}\text { The anomaly in January has been } \\
\text { observed. }\end{array}$ \\
\hline $\begin{array}{l}\text { Werner F. M. } \\
\text { De Bondt, Yaz } \\
\text { Gülnur } \\
\text { Muradoğlu, } \\
\text { Hersh Shefrin } \\
\text { and Sotiris K. } \\
\text { Staikouras } \\
\text { (2015) } \\
\end{array}$ & $\begin{array}{l}\text { Behavioural } \\
\text { Finance: Quo } \\
\text { Vadis? }\end{array}$ & $\begin{array}{l}\text { Presenting an assessment } \\
\text { of foundations of finance } \\
\text { and the future of } \\
\text { behavioural finance }\end{array}$ & $\begin{array}{l}\text { A new set of asset pricing models has } \\
\text { been proposed by the addition of } \\
\text { behavioural elements to the } \\
\text { conventional framework. }\end{array}$ \\
\hline $\begin{array}{l}\text { David } \\
\text { Hirshleifer } \\
\text { (2015) }\end{array}$ & $\begin{array}{l}\text { Behavioural } \\
\text { Finance }\end{array}$ & $\begin{array}{c}\text { The effects of judgments } \\
\text { and decision prejudices } \\
\text { with the investigations } \\
\text { arbitrage and asset } \\
\text { allocation and why firms } \\
\text { manipulate inefficient } \\
\text { prices }\end{array}$ & $\begin{array}{l}\text { The behavioural finance needs to } \\
\text { move beyond and modify social } \\
\text { finance which can cover the } \\
\text { responses of how social interactions } \\
\text { and financial speculations are } \\
\text { affecting financial outcomes. }\end{array}$ \\
\hline $\begin{array}{l}\text { Bilgehan Tekin } \\
\text { (2016) }\end{array}$ & $\begin{array}{l}\text { The Financing } \\
\text { Decisions of } \\
\text { Firms: } \\
\text { Behavioural } \\
\text { Perspective }\end{array}$ & $\begin{array}{c}\text { The effects of } \\
\text { overconfidence and loss } \\
\text { aversion biases are } \\
\text { investigated in order to } \\
\text { understand decision- } \\
\text { makers' approach to } \\
\text { financial securities. }\end{array}$ & $\begin{array}{l}\text { The personal staff, who has } \\
\text { responsibility in finance, has these } \\
\text { biases. }\end{array}$ \\
\hline $\begin{array}{l}\text { Meltem } \\
\text { Gürünlüu (2018) }\end{array}$ & $\begin{array}{l}\text { Corporate } \\
\text { Finance } \\
\text { Decisions from } \\
\text { the Perspective } \\
\text { of Behavioural } \\
\text { Finance Theory }\end{array}$ & $\begin{array}{l}\text { Integrating behavioural } \\
\text { finance in corporate } \\
\text { finance. }\end{array}$ & $\begin{array}{l}\text { Psychological factors have significant } \\
\text { effects on the decisions of corporate } \\
\text { finance managers. }\end{array}$ \\
\hline $\begin{array}{l}\text { Robert A. Olsen } \\
\qquad(2019)\end{array}$ & $\begin{array}{l}\text { Behavioural } \\
\text { Finance and Its } \\
\text { Implications } \\
\text { for Stock-Price } \\
\text { Volatility } \\
\end{array}$ & $\begin{array}{l}\text { Applications of } \\
\text { Behavioural Finance in } \\
\text { Stock Price Processes }\end{array}$ & $\begin{array}{l}\text { New theories such as chaos and } \\
\text { adaptive decision making can } \\
\text { support investor while solving the } \\
\text { puzzle of stock-price variations. }\end{array}$ \\
\hline $\begin{array}{l}\text { Richard H. } \\
\text { Thaler (2019) }\end{array}$ & $\begin{array}{l}\text { The End of } \\
\text { Behavioural } \\
\text { Finance }\end{array}$ & $\begin{array}{c}\text { Investigation of why } \\
\text { behavioural finance has } \\
\text { conflicts with the rational } \\
\text { part of investing }\end{array}$ & $\begin{array}{l}\text { In future, the financial models will be } \\
\text { based on behaviours rather than } \\
\text { classical methodologies. }\end{array}$ \\
\hline
\end{tabular}


According to the reasons mentioned above, this research is outlined in order to fill the gap in the literature by exploratively scanning the medical elements of investment behaviours in financial markets.

\section{EFFICIENT MARKET HYPOTHESIS (EMH)}

First of all, theoretically, the assertors of EMH claim that the prices of financial securities display entirely relevant and available information in the markets. Therefore, they claim that there will be no significant difference between professional traders who are actively taking risks in short time ranges to get profit with higher risk appetite and average investors who have low-risk tolerance with focusing on long term sustainable income. In other words, the investors, who provide their income from trading professionally, cannot continuously defeat the markets, and passive investors can earn the same profits in ordinary as the active ones do. Briefly, the prices and valuations in financial markets are consistently right, which vary relative to the randomly incoming data, information or news according to the EMH. ${ }^{2}$

Second, the speculative trading strategies can be costly and transform into a disastrous game in comparison with the passive investment management approaches due to the claimers of the EMH. In essence, the behaviour, which underlies professional active investing can be observed as buying or selling in short term time scales by searching for the mispriced assets which may exploit, can be explained with the emotional and psychological part of finance. Hence, if there is no significant difference between an active and passive investor according to the earning opportunities in the financial markets as EMH stated, the emotional factors can play a role in behaviours of the investors who constitute the financial markets.

There are three forms of EMH which can be defined as weak, semistrong and robust in order to categorise how the hypothesis supports the asserters' perception in the financial markets. According to the weak form of the EMH, entire latest stock prices perfectly reflect all the past and present stock market information. Also, this information is reflected on prices and their patterns which can be followed with stock charts and trends. However, the main agreement is that there is no significant

\footnotetext{
${ }^{2}$ Sebastian Harder, The Efficient Market Hypothesis and Its Application to Stock Markets, pp.5
} 
correlation between past price tendencies and future price movements, so all the price activities alter independently. On the other hand, the significant inferences of the semistrong form of EMH are that the investors, who take a position concerning to the released public available information, are not going to be able to gain over than average income because the security prices have been already reacted to the news. Finally, the strong form of EMH covers both the weak and semi-strong forms as stock prices display all the available information which include public, private, or else. Hence, consistently derive higher than average profits are not probable. ${ }^{3}$

\section{BEHAVIOURAL FINANCE}

The behavioural part of finance has been expanding its scope for exploring the investors' decisions in markets with the combination of cognitive psychological factors and traditional economics. Mainly, the efforts of behavioural finance have focused on the irrationalities of the markets which are formed by human factors. Therefore, the main goal of this field is to suggest explanations for why and how the markets can be ineffective. There are mainly four significant arguments which are commonly accepted by the experimental finance scholars as heuristic, framing, emotions and market effect.

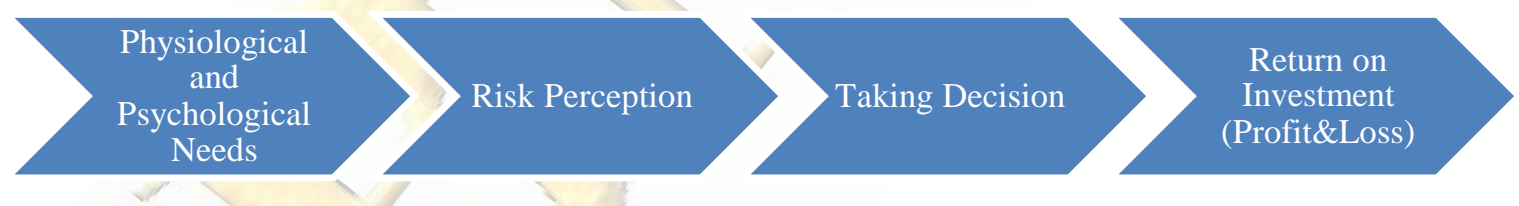

Figure 1. Investment Cycle

(Source: Created by the author.)

In the heuristic approach, the mental shortcuts are used for simplifying the complex cases or problematics. Therefore, in the investment environment, the uncertainties and chaotic conditions can be disentangled through the applications of heuristic biases by the decision-makers to catalyse their actions in trading. On the other hand, investors can select different options from the alternative financial securities when the problem is framed in verified ways, but the realities will remain constant, 
which is defined as framing behaviour by psychologists. Correspondingly, emotions which can be commonly explained as unconscious human needs, fancies, greeds and fears play a significant role in the decision-making processes of the investors. As a result, such these kinds of factors which are defined as cognitive failures or biases have effects on market sentiments of the investors, are accepted as the primary drivers of the financial market by behavioural scientists of finance. However, adversely, the thesis of standard finance sticks up for the paradigm which can be stated as such these mistakes would not transform the asset prices because if security values depart from their standard worths, the rational arbitragers will offset the market trend.

\section{THE FUNCTIONS OF BRAIN IN INVESTMENT BEHAVIOUR}

Fundamentally, the emotional thoughts and logical reasoning are being performed by brain functions in order to improve human perception for taking decisions. In essence, two types of thinking mechanism are being formed by the different parts of the brain for shaping the behaviours according to varied objectives of decisions. Within the context of meeting the needs for living, the automatic processing of information, which is required through unconscious behaviour, is occurred under the control of the automatic system of the brain. The amygdala, basal ganglia, lateral cortex, ventromedial prefrontal cortex, and dorsal anterior-cingulated cortex are the parts of the brain which have roles on the automatic system. Also, most of the emotional thoughts are formed in the striatum or also known as basal ganglia and limbic fields of the brain. Mostly, the limbic system works as a hotspot of mind for following rewards and staying away from risks as fast as possible in order to stay alive. The amygdala which is a kind of structure of limbic system supports reflexive thinking while making the evaluations of emotions to transform them into reactions as fear, discomfort or satisfaction, for motivating a person to take action. ${ }^{4}$

\footnotetext{
${ }^{4}$ Matthew L. Dixon, Ravi Thiruchselvam, Rebecca Todd, Kalina Christoff, Emotion and the Prefrontal Cortex: An Integrative Review, pp.4, 5
} 


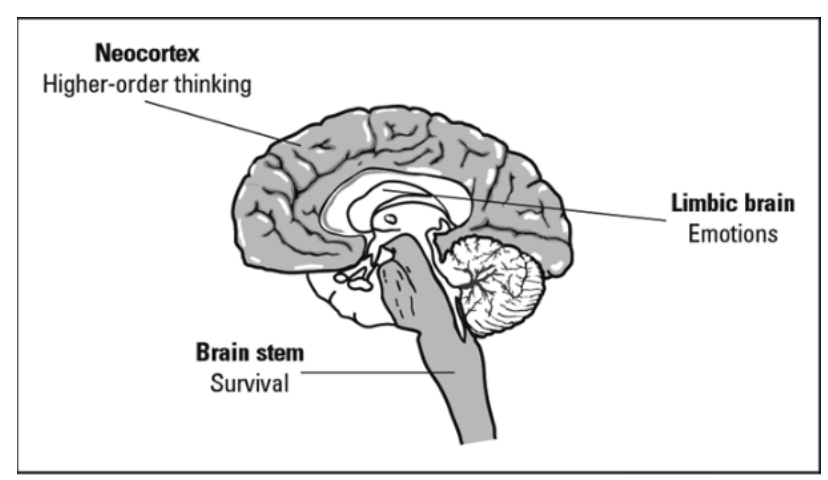

Figure 2. The Brain Structure

Source: http://www.ascd.org/publications/books/101269/chapters/A-Walk-Through-the-Brain.aspx

According to the research studies, the major central parts of the reward circuit of the brain are placed along with the medial forebrain bundle (MFB). This circuit is formed by two main centres which were defined as the ventral tegmental area (VTA) and the nucleus accumbens as well as the amygdala is covered by this line. Risk and reward perceptions of human beings are mostly organised by the MFB or also stated as a reward circuit which has a link function between the VTA and lateral hypothalamus. Besides, the connection between VTA neurons and amygdala shows that the most primitive regions of the brain can have predominant impacts on investors' behaviours in financial markets.

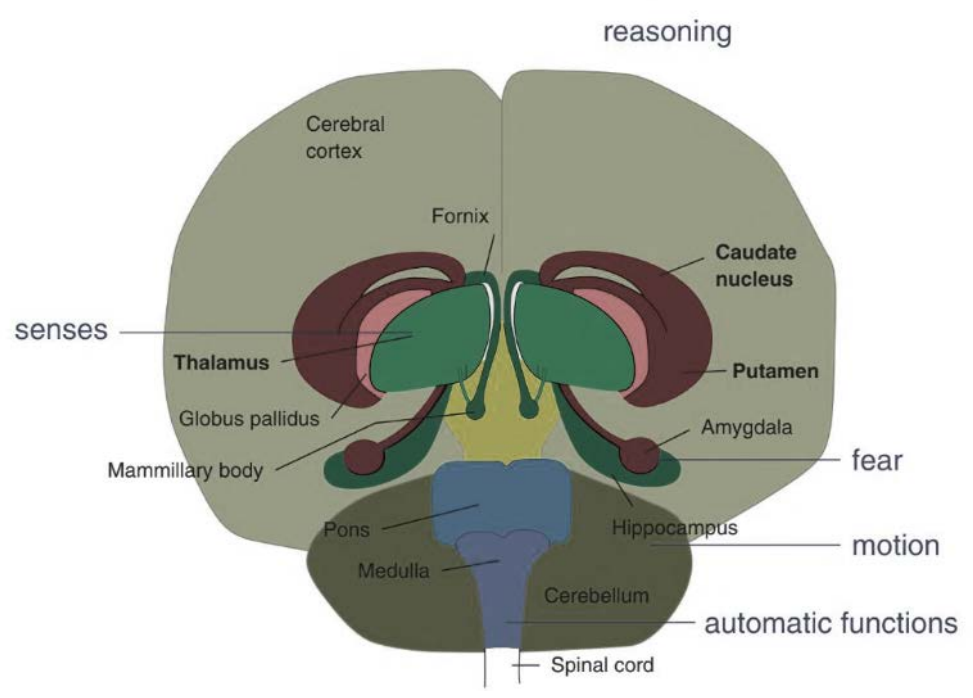

Figure 3. The Human Brain

Source: Kremena K. Bachmann, Enrico G. De Giorgi and Thorsten Hens, Behavioural Finance for Private Banking: From the Art of Advice to the Science of Advice, pp. 48 
Within the context of the relationship between the processing mechanism of the human brain and the speed of information release and flow in financial markets shows that there may be conflicts between the investors' behaviours and the efficiency of markets, because in assumption. However, all the information is related to the financial markets can be achieved by all the investors in perfect conditions, the price reactions to this news cannot be cured most of the time because the perceptions of investors are going to vary. Also, the root cause of these diversifications in investor behaviours which are framed with cognitive errors in behavioural finance can be explained through the hypothesis as the efficiency of human mind reduces when a person has to shift his or her attention from one subject to another. Therefore, as a nature of dynamic conditions in financial markets, the investors' mind should be multitasking in order to adapt emerging information and events. Similarly, the minds of active traders who professionally take positions in financial markets to get expected return of their investments in short time frames as mentioned before, filter the information what they face while taking decisions. Therefore, the reflexive system plays a significant role in financial markets while understanding the similarities and differences in trends of the securities. However, the reflexive system which has been serving human beings for thousands of decades is not sufficient for the modern world which we are living now, because there are a considerable number of complexities in today's life and financial markets than only immediate threats. That is why the reflexive system, which can cause unmethodical decisions that result in unexpected losses, should be controlled by the investors. Correspondingly, the amygdala part of the brain takes in place in order to affect the motor or autonomic nervous system. Also, the inputs which are received from early detecting process fields that consist of occipitotemporal area, insula and cortices, transform into outputs in the amygdala to augment neural representation of biochemically vital impulses. In connection with exploring the irrational behaviours of investors in financial markets, the amygdala has a crucial role in learning the threats and opportunities around the environment according to the experimental researches. 


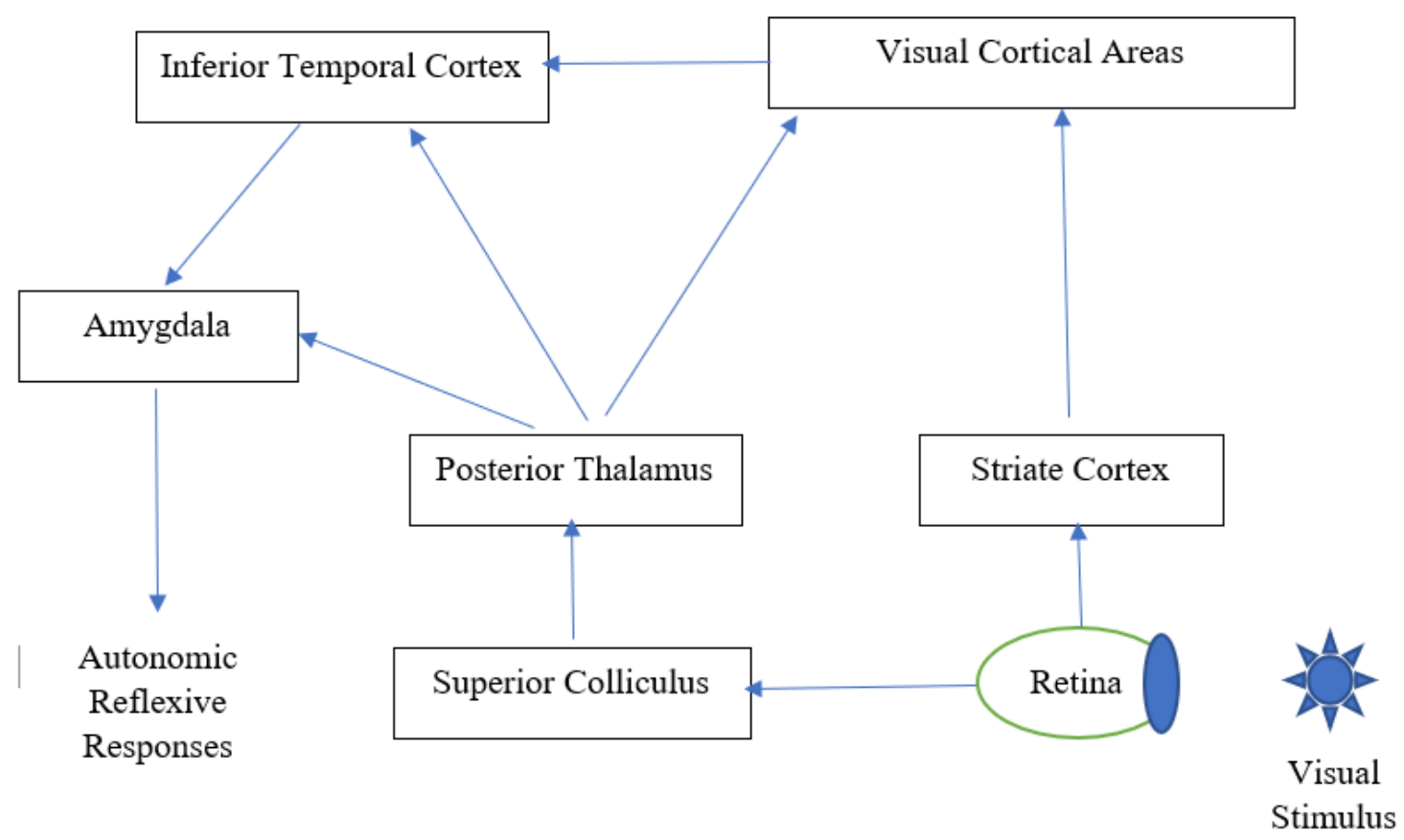

Figure 4. The Role of Amygdala in Reflexive System

Source: Aruna Chakraborty\&Amit Koonar, Emotional Intelligence: A Cybernetic Approach, p.95

The underlying reasons of the problematics of this research study, which is determined as to why investors' decisions are varying in a wide range of scale in financial markets via irrationality, can be examined through interdisciplinary approaches that including finance, economics, neurology, endocrinology and behavioural sciences. Therefore, the hormones which are performing as a chemical messenger have impacts on emotions and behaviours must be investigated as a moderator in order to understand the connection between decision-making process and the human mind, because hormonal system affects the brain parts which have a role in the activation of the reflexive system. Particularly, hormones such as testosterone, dopamine, serotonin and cortisol have effects on the behaviours and decisions of the investors. For example, cortisol which has function in supporting the human body for keeping the glucose amount of the blood in normal levels when a person is stressed. Accordingly, investing in financial markets such as stocks and derivatives, which involves excessive risks, can cause extra pressure on finance professionals such as hedge fund managers and active traders. Also, the efforts of such kind of investors which can be framed relative to the expected returns and risks generate extra stress and high level of cortisol. For instance, an unexpected event or 
high volatility develops in the market, analeptic hormones such as testosterone and cortisol are emitted to the bloodstream, and these hormones may cross the blood-brain barrier as well as they affect the functioning of synapses between neurons and the perceptual mapping in brain. Furthermore, cortisol and testosterone sensors are located along with the brain that is covered by the frontal cortex, amygdala, hippocampus, and nucleus accumbens. Significantly, the dopamine release, which is a kind of chemical messenger like serotonin affects the capability of the brain in terms of managing circumstantial risk, depends on testosterone and cortisol level of the blood and then the brain.

The experimental studies, which consider the testosterone level as a predictor and monetary risk-taking as output, prove that includes the sample who have a higher proportion of diffusive testosterone hormone in the blood, invest their capital to the risky assets which have above the average expected return and significant probability of loss. On the other hand, cortisol has an inverse relationship with risk-taking behaviour in comparison with testosterone. Accordingly, cortisol levels elevate during the period of stress in order to limit risk appetite.

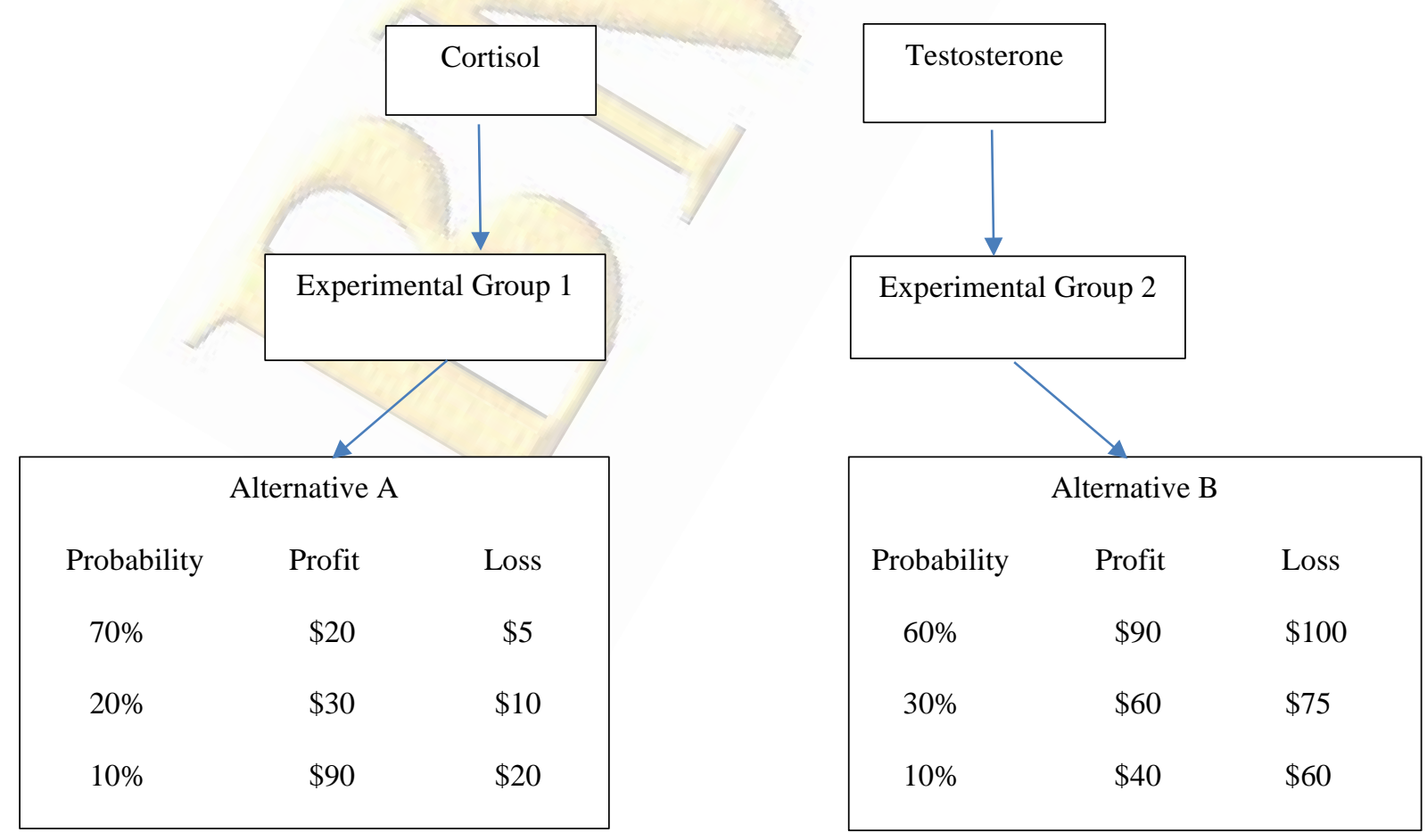

Figure 5. The Representative Model for How the Cortisol and Testosterone Hormones Affect Risk-Taking in Alternative Investments 


\section{FINDINGS AND RECOMMENDATIONS}

According to the mentioned reasons, the neural pathways between VTA and amygdala have a significant role on risk and reward perception of the investors through taking the support of an endocrine system which circulates testosterone and cortisol hormones in order to offset the stress during the time of risk-taking behaviour. The mechanism between neural and hormone system is one of the determining factors in order to explain why investors' behaviours are varying in extensive scale and cause cognitive errors in financial markets. Biologically, the sequential risk management process in financial markets starts with the perception of financial information by the investor mind that stimulates the endocrine system which activates the testosterone hormone for motivating the investor to take the risk as well as causes stress, finishes with releasing of cortisol in order to reduce the stress level. As a result, the balance between testosterone and cortisol hormones has significant role inaction of the investors, because there is a positive correlation between testosterone level and risktaking as well as there is a negative correlation between cortisol level and risky behaviours.

Additionally, the past studies support the discoveries of this research as the investors, who have sociological, psychological and physiological side, are not trading robots or rational machines by taking their decisions without emotions which induce cognitive errors. However, the previous researches consider the subject from the general viewpoint in terms of just trying to understand the security prices in financial markets by making comparisons between traditional and behavioural finance. Therefore, the assumptions and proposals in this research are presented by observing the main elements of the biochemical processes in human body and brain which trigger and control the investment behaviour for attempting to investigate the root causes of how the emotions are emerging and taking role while the investment decisions are taken.

This research can be enhanced with advanced clinical studies in order to investigate that how the primitive areas of the brain can be trained or controlled which have significant functions in the optimal distribution of hormones because particularly the balance between testosterone and cortisol affects the performance of investors. 
Furthermore, the study can be improved with the complementary examinations of why and how the dopamine and serotonin circulations in the brain are provided with understanding their effects on investment decisions. 


\section{REFERENCES}

Bachmann, K. K., De Giorgi, G. E. and Hens, T. (2018). Behavioural Finance for Private Banking: From the Art of Advice to the Science of Advice, (pp. 48).

Bechara, Antoine, Damasio, H., Damasio, A.R. (2000). Emotion, decision making and the orbitofrontal cortex. Cerebral Cortex 10:3, (pp. 295-307) .

Chakraborty, A., Konar, A. (2009)., Emotional Intelligence: A Cybernetic Approach, Springer, (pp. 9495) .

Coates, John M., Herbert, J. (2008). Endogenous steroids and financial risk-taking on a London trading floor. Proceedings of the National Academy of Sciences 105:16, (pp. 6167-6172).

Frydman, C., Camerer, C. (2016). Neural evidence of regret and it's implications for investor behavior. The Review of Financial Studies, 29:11, (pp. 3108-3139).

Harder, S. (2008), The Efficient Market Hypothesis and Its Application to Stock Markets, (pp. 5) .

http:/ / www.ascd.org/publications/books/101269/chapters/A-Walk-Through-the-Brain.aspx

Lee, A. C., Lee, J. C., Lee, C. F. (2016). Financial Analysis, Planning\&Forecasting: Theory and Application, (pp. 287-288) .

Ricciardi, V. (2008). Risk: Traditional finance versus Behavioural finance. In handbook of finance, 3 : Valuation, financial modeling and quantitative tools, ed. Frank J. Fabozzi, (pp. 11-38) . Hoboken, NJ: John Wiley\&Sons.

Smith, C. W. (1999). Success and survival on Wall Street: Understanding the mind of the market, $2 \mathrm{~d}$ ed. Lanham, MD: Rowman and Littlechild

Vergano, D. (2006). Study: Ask with Care: Emotion rules the brain's decisions. USA Today, August 7, (pp. 4) .

Wolozin, H., Wolozin, B. (2007). The unconscious in economic decision-making: Convergent voices. Journal of Socio-Economics 36:6, 856-64 